\title{
NAUFRÁGIO: METÁFORA DA EXISTÊNCIA
}

Lucia Helena (UFF)

Resumo: $\mathrm{O}$ artigo leva em consideração o tema do naufrágio como extensão da viagem em seu papel de condutor de uma concepção da existência. A partir deste ponto de vista teórico, estuda as relações de mobilidade cultural presente na história de vida dos personagens nucleares do romance $O$ náufrago, de Thomas Bernhardt (2006): o narrador não nomeado, Wertheimer e Glenn Gold.

Palavras-chave: Existência; Naufrágio; Mobilidade cultural.

Abstract: This article takes into account the theme of the shipwreck as an extension of the voyage in its role of conducting a conception of human existence. From this theoretical starting point, the essay studies the multiple interrelationships of cultural mobility that are the basis of the behavior and feelings of the tree main characters of the novel The Adrift, by Thomas Bernhard (2006): the anonymous narrator; Wertheimer and Glenn Gold.

Keywords: Existence; Shipwreck; Cultural Mobility.

Com uma palavra, aniquilamos uma pessoa. [...] Vinte e oito anos depois de Glenn ter dito a Wertheimer no Mozarteum que ele era um náufrago, e doze anos depois de tê-lo repetido nos

Estados Unidos, Wertheimer se matou.

Thomas Bernhard, O náufrago

Michel de Montaigne (1533-1592), em seus Ensaios (1580), intui que, ao contrário do que se costuma pensar, os homens se aproximam mais uns dos outros pelas patologias que carregam do que pelas afinidades que têm em comum. Eis uma boa premissa para se avaliar o romance $O$ náufrago (2006), publicado em 1983, no qual a relação conturbada mantida pelos personagens-chave do relato - Glenn Gould, 
Wertheimer e o narrador, cujo nome se desconhece - parece confirmar o ponto de vista do escritor e filósofo francês.

Extensa, a escrita deixada por Bernhard (1931-1989) vai além da narrativa romanesca, espraiando-se pelo teatro e por seu conhecimento musical. Ele nos deixou dezenove romances, dezessete peças de teatro, dentre outros livros breves e autobiográficos. Em uma obra de múltiplas facetas, destaca-se a inter-relação da ficção com a memória. Traço que adquire, nas mãos do escritor, forma renovadora, descortinando, à primeira vista, uma introspectiva que, no entanto, vai além da tradição de combinar vida e arte, que havia sido consagrada pelos modernistas.

Na literatura brasileira, quanto à ficção que investiga o eu e constrói novas formas de acesso às dimensões profundas da intimidade, vem à tona o nome de Clarice Lispector, cujo trabalho pode ser comparado, pelo talento, ao de Bernhard. Ela trata da confluência entre a ficção e biografia, em $A$ hora da estrela, texto no qual enreda dados pessoais com dados biográficos de sua personagem nordestina a quem dá o nome de Macabéa.

Bernhard e Lispector empreendem renovação semelhante que, em geral, adotando o narrador em primeira pessoa, cria pistas falsas de que estão abrindo sua intimidade ao leitor. 
É uma pista traiçoeira porque suas narrativas não resultam de ato confessional ingênuo, no qual cuidariam de falar de si mesmos. Antes, provêm de um perspicaz amálgama da experiência biográfica com a experiência ficcionalizada, por eles construída como uma expressão de alteridade. Essa trama indica uma complexa montagem e só se torna clara e acessível para os leitores que conheçam bem a obra e a vida dos dois autores, passando despercebida para o leitor comum. Lispector e Bernhard não enquadram o memorialismo no modelo consagrado pelo século XIX, no qual a memória disfarça o componente ficcional e simula um pacto pragmático e informativo com o leitor, levando-a a apreender o texto como uma confissão e registro da vida do autor. Ao contrário disso, os dois escritores tecem em sua ficção regiões de um memorialismo brumoso, apenas identificável de forma muito sutil. Ambos, ao fim e ao cabo, se distanciam do percurso confessional, caso este seja concebido como uma forma de mergulho no eu profundo, pois seguem um curso diferente, por exemplo, do que JeanJacques Rousseau realizou em suas Confissões.

Em A hora da estrela, Rodrigo S M é um narrador interposto que discute como narrar a história de Macabéa, com ela rivalizando o protagonismo. Em $O$ náufrago, 
o narrador se utiliza da distinção entre pensei \& disse, criando uma técnica de repetições com a qual logra afastarse do que comumente se realizava nos romances tradicionais que adotam a primeira pessoa como foco do ato narrativo. Interessante notar que, tanto no livro de Bernhard, quanto no de Lispector, o traçado confessional aproxima-se da técnica naturalista de expor traços crus, duros, na composição de personagens desse híbrido ficcional incomum. O recurso ao veio recessivo do naturalismo ronda essas duas obras, podendo ser visto como forma de responder aos desafios de um ato narrativo renovador, fazendo com que este não só destoe das antigas chaves tipificadas pelos "romances de formação e aprendizagem", mas também escape do matiz dos romances de tese, caracterizadores de certa faixa da ficção do final do século XIX. Eles renovam ao adotar técnicas provocantes, na utilização do discurso indireto livre e do fluxo da consciência das fórmulas legadas pelo modernismo, que ardilosamente revisitam e metamorfoseiam. Pode-se considerar, com Benedito Nunes, que transformam, desse modo, a via introspectiva do ato narrativo. Diz ele que:

num grau paroxístico que leva ao paradoxo na linguagem, inverte-se, pois, na alienação da consciência de si. Pelo naufrágio da introspecção a personagem desce às potências obscuras, perigosas e arriscadas 
do inconsciente, que não tem nome. Depois desse mergulho no subsolo escatológico da ficção, nas águas dormidas do imaginário, comuns aos sonhos, aos mitos e às lendas, a voz reconstruída de quem narra só poderá ser uma voz dubitativa, entregue à linguagem - aos poderes e à impotência da linguagem, distante e próxima do real, extralinguístico, indizível. (1989, p.68)

O sentimento do fracasso da linguagem e do fracasso da própria existência acompanha de modo subjacente o jogo da narrativa de Bernhard em $O$ náufrago, no qual, na tradução brasileira, a articulação bastante reiterada entre "penso, disse" torna-se um refrão que ecoa ao longo da fala do narrador, traduzindo-se, neste, tanto a busca de se tornar mais complexa a narrativa em primeira pessoa, quanto à busca de se expor a insuficiência da linguagem que, sempre equívoca, é muitas vezes incapaz de unir pensamento e fala. Com perspicácia, o escritor trabalha a insuficiência de um dizer dubitativo quanto à capacidade de se traduzir o pensamento em palavras. Dessa maneira, põe em tensão a narrativa como um ato consciente e as camadas inconscientes que, nela se inserindo, "nos falam", ao se intrometerem no recorte do que o discurso autoconsciente consegue esboçar. Essa é uma das técnicas fundamentais do trabalho com a linguagem elaborado por esse grande escritor. Como nos diz Giorgio Agamben (2002), e sua ponderação 
condiz com o procedimento adotado por Thomas Bernhard em O náufrago, "Solo la parola ci mette in contano [sic] ${ }^{1} c o n$ le cose mute." ("Só a palavra nos põe em contato [contatto] com as coisas mudas") (2002, p.103 - tradução nossa).

Mote a ser glosado, o tema do livro é simples: três jovens se conhecem num conservatório de música, ao buscarem, pelo amor à música e ao piano e pela extrema ambição do sucesso, estudar com Horowitz, considerado um mestre dos mestres. O gosto pela música e a ambição de se tornarem virtuoses unem os três personagens que se tornam vítimas de uma forma exacerbada de amor e do sadomasoquismo com que se relacionam com o objeto amado (a música), consigo mesmos e entre si.

Reunidos na Áustria e estudando no Mozarteum (Bernhard também estudou música e teatro no Mozarteum de Salzburg, de 1955 a 1957), os personagens de $O$ náufrago marcham em trajetória autodestrutiva aparentemente impulsionada pela busca do belo e da execução perfeita. Como, então, a busca do belo pode culminar em uma derrocada?

A inversão dos paralelismos entre o belo e a perfeição, entre a paz e a felicidade, entre a calma e a vida produtiva

1 Deve haver um erro de impressão no original italiano. A expressão "in contano" remete para contagem, não para contato, o que deixaria a frase sem sentido. Por esta razão, traduzimos a expressão como se fosse "in contatto", o que permite ao leitor resgatar uma possibilidade literal de sentido. 
(e seus derivados) pode ser pensada a partir da discussão de Nietzsche - e Bernhard alinha seu romance com esse pensamento - acerca da percepção de não serem a calma e a serenidade, em um pensamento linear e causal, que gratificam o espectador do naufrágio. Para Nietzsche, é o poder do sofredor o que conta, de acordo com Hans Blumenberg (1997, p.21-24). E aqui se está pensando em algo como apaixonar-se pela intensidade do desastre, na dor e na delícia de sofrer, na intensa experiência de ser tragado pela força de energias temidas e apresadas no inconsciente, de temer e de amar, ao mesmo tempo, o desafio das forças mortais de Tanatus, tornadas impulsos intensamente eróticos.

Apaixonar-se pelo próprio fracasso, ainda que isso conduza ao suicídio de Wertheimer, é uma espécie de dependência para esse personagem, que age como se fosse alguém que se torna condicionado ao uso de uma droga, ou se torna extremamente subordinado a alguém ou, até, atua como vítima de uma perturbação emocional grave. Podese dizer que a dependência de Wertheimer (a de querer ser um gênio e de tornar-se um virtuose ao piano, e não aceitar qualquer frustração desse desejo) é vivida por ele de forma doentia. Assim como sua vida, a morte do personagem 
é conduzida por intensa dependência ao excesso, revelando a constituição trágica da qual perigosa e mortalmente se aproxima.

No caso desses três personagens de Bernhard, a dependência de atingirem a perfeição é a desmedida comum aos três. Dois deles são figuras da ficção: o narrador em primeira pessoa, cujo nome resta oculto, e Wertheimer, o suicida; o terceiro, Glenn Gould, é figura extraída da cultura musical canadense e norte-americana, e que se tornou um executante extraordinário das Variações Goldberg, de Johan Sebastian Bach, com isso obtendo fama mundial. Ele também figura como uma forma que a narrativa tem de tratar da absorção da arte pela mídia e pela sociedade do espetáculo, que torna o virtuose um técnico mais do que um artista de talento incontornável, em uma sociedade cuja tecnologia vai substituindo com êxito, e corrigindo, as falhas da voz e do controle motor humano.

A relação triangular que todos eles mantêm é de natureza voyeurística e narcísica e mescla perversões sadomasoquistas na forma pela qual os personagens vivem e se inserem, como que deliciados, em experiências para as quais confluem a dor e o sofrimento. Um sentimento de perturbação alimenta o contato entre eles e é um firme alicerce do comportamento 
que mantêm entre si os três amigos. A questão do ensinar e do aprender é um forte eixo dessa relação. Elo que vincula o texto de Bernhard a outros textos da cultura alemã - como os romances de aprendizagem - e a outras artes e cenas culturais e aforismas subjacentes.

Os três personagens foram alunos do Mozarteum, em graus diferentes de aprendizado, embora pudessem ser colocados no topo da pirâmide do talento dentre os demais alunos de Horowitz. Só um deles, todavia, considerou-se e foi considerado um gênio: Glenn Gould. Claro que, de forma muito complexa, o texto de Bernhard dialoga com os romances de fundação, focalizando o tema do aprendizado e do ensinamento de modo perverso, e remetendo o leitor ao texto The confusions of Young Törless (1906), tido como um romance de aprendizagem de Robert Musil (1880-1942), obra explicitamente referida por Bernhard, na fala do narrador:

Diante de um copo de água mineral, eu pretendia reler depois de vinte anos $O$ jovem Törless, de Musil, mas não consegui; não suporto mais narrativas: leio uma página e sou incapaz de prosseguir. Não suporto mais descrições. Por outro lado, tampouco consegui matar o tempo lendo Pascal; conhecia os Pensamentos de cor, e a fruição prazerosa de seu estilo se esgotou logo. Contentei-me, pois, em contemplar a paisagem. A impressão que as cidades causam, quando se passa por elas, é de 
decadência; as casas dos camponeses foram todas arruinadas, já que seus proprietários trocaram as janelas antigas por novas e horríveis janelas de plástico. (BERNHARD, 2006, p.51)

Musil se identificou com a geração que floresce na década de 1890 e se torna um aficionado de Mallarmé, rejeitando a premissa naturalista de que a arte devia refletir uma realidade pré-existente (COETZEE, 2001, p.v). Essa geração experimentou sucessivas fases de desorganização social e psíquica entre 1890 e 1945, vivenciando uma crise nas artes que deu origem às várias reações modernistas. Tendo vivido até 1942, Musil considera que o mais grave problema da cultura alemã, da qual a Áustria onde nasceu fazia parte, era sua tendência para compartimentar separadamente a razão e o sentimento. Ele via essa divisão muito claramente entre os cientistas com os quais trabalhou, devido à sua formação inicialmente técnica. A metáfora-chave do livro baseiase, segundo Coetzee na sua introdução à tradução inglesa do romance, no fato de que os fundamentos do real não têm fundamento, ou seja: o mundo da vida diária não tem existência real nem razoável. E esse espírito do paradoxo continua a ser explorado em seu livro mais famoso, Um homem sem qualidades. Essa perspectiva o coloca, como se pode ver, fora da ideia que lhe consagrou a crítica, 
de produzir um romance de formação, ainda que, como obra da juventude, o livro que tem Törless como personagem, ofereça as bases, que estão também na obra de Bernhard, de que "the present is nothing but a hypothesis that one has not yet finished with" - "O presente não é nada, apenas uma hipótese da qual alguém ainda não se desfez" (COETZEE, 2001, p.xiii - tradução nossa).

Nesse sentido, Bernhard aponta em $O$ náufrago para a geração de Musil, que é também a geração de Wertheimer e do narrador, fixando-Ihes um sentido paradoxal para a existência. A viagem do olhar da elite para o mau gosto dos que não pertencem a seu grupo, o mundo em decadência, a corrosão irônica do desprezo do narrador pelos suíços (o que pode simular uma crítica comum entre alemães muito conservadores de considerarem que os suíços, mesmo no cantão dito alemão, não sabem falar bem esse idioma), a melancolia que aos poucos vai invadindo tudo e todos, num fascínio pela infelicidade humana, são questões pouco a pouco atribuídas pelo narrador a Wertheimer, como se elas apenas o caracterizassem; embora tudo isso se manifeste como envoltório do mundo do próprio narrador e, de certo modo, do Glenn Gould visto por ele. E isso porque a narrativa em primeira pessoa já traz em si mesma um ponto de vista do qual se pode (e se deve) duvidar como "verdade". 
Enfim, a narrativa cuida de criar um mundo sufocante e em sufocação, no qual as bibliotecas são, "por assim dizer, penitenciárias onde trancafiamos nossos grandes intelectos, Kant, é claro, numa cela só para ele, assim como Nietzsche, Schopenhauer, Pascal, Voltaire, Montaigne, todos os grandes em celas individuais" (BERNHARD, 2006, p.58). O mal-estar da civilização, se assim se pode pensar, entra pelos poros dessa narrativa e contamina o leitor do clima de decadência e ruína. Acenos de aproximação e amizade constroem uma rede de mal-entendidos da qual os três amigos não conseguem escapar.

A referência ao romance de Musil, embora mereça ser estudada como mais intrincada do que isso, remete, em primeiro lugar, a uma forma de revisitar o cânone dos romances de aprendizagem e de, retomando-os, transformálos, utilizando-os como uma maneira de criticar a sociedade em que surgiram. No romance de Musil, referido pela narrativa de Bernhard, a ação se passa no início do século XX, na Áustria, e um jovem estudante, Törless, tímido e inteligente, observa o comportamento sádico de seus amigos de escola e não toma nenhuma providência quando eles escolhem como vítima uma colega de sala, que torturam sem piedade. Este romance, The confusions of Young Törless, 
tido como de cunho filosófico, narra a história da formação de um adolescente, num internato do Império AustroHúngaro. Para alguns críticos, é um prenúncio dos estados autoritários que surgiram depois da I Grande Guerra. Para outros, é uma forma doentia de simbolizar o enterro da individualidade e, além, o estudo da natureza humana na perturbadora e violenta sociedade moderna. Para Coetzee, o romance de Musil é, mais especificamente, a exploração, pela narrativa da crise interior do Jovem Törless (seu primeiro nome não é dado na narrativa), por ter participado, com sua omissão, do ato sádico perpetrado por seus colegas na academia de elite que frequentavam. O exame dos efeitos desse comportamento abusivo em uma consciência desagregada é trabalhado no âmbito da discussão da ética e da formação psicológica, dando à novela uma substância que tange operações internas e profundas do desejo sexual na alma daquele jovem (COETZEE, 2001, p.x-xi). A viagem de introspecção é comum a Musil e a Bernhard, embora feita por vias narrativas diferentes.

O náufrago convoca ao primeiro plano não apenas os três protagonistas, mas sua dolorosa convivência com pesados problemas da cultura europeia, anterior e posterior ao Holocausto, e à crise por eles provocada, transformando 
os homens em seres em ruínas. Ao viverem para escrever, como faz o narrador, ao viverem para tocar piano com virtuosismo, como Glenn Gould, ou, não o conseguindo, como Wertheimer, que termina por se suicidar, todos os três tornam-se náufragos, submetidos, pela forma sufocante com que reagem aos sentimentos de dor e prazer, à dificuldade de vivê-los e de expressá-los para si mesmos e o mundo.

Em resenha sobre $O$ náufrago, Kevin Bazzana² afirma que "o romance é fascinante tanto como uma obra literária, quanto como um documento ${ }^{3}$ na história de Glenn Gould". A expressão "documento", usada por Bazzana, é inadequada ao romance. Apesar de Gould ser uma figura retirada da "vida real", o livro não é um documento, mas um romance que converte os fatos em ficção, sem prejuízo, ao contrário, da força que os eventos têm fora da linguagem literária. A importância dessa resenha consiste em acentuar o caráter híbrido da escrita de Bernhard, que junta em um mesmo texto material que, na matriz, pode ser visto como de procedência interna e externa à literatura.

Escrito sob a forma de uma narrativa em primeira pessoa, num contínuo monólogo interior, e à exceção de três breves

\footnotetext{
2 Em resenha acessada na internet em 07.Dez.2011 e intitulada "The loser reviewed". http:// www.collectionscanada.gc.ca/glenngould/028010-40.05.07-e.html.

3 A fidelidade ao Glenn Gould real não é tão grande assim. Bernhard se permite adicionar elementos de ficcionalidade que passam, ao longo de suas páginas, a incidir sobre a construção do personagem e, em especial, sobre datações, roteiros de viagem.
} 
parágrafos iniciais, o livro adota discurso sem quebras de parágrafos, como se a disposição do texto na página representasse, de saída, o caráter de emparedados que ressalta das relações entre os personagens e deles consigo mesmos. O livro consiste, quase inteiramente, na ruminação da memória do narrador, que relembra sua relação com os dois amigos pianistas, todos eles matriculados em um curso de música, em Salzburg, na Áustria, em 1953.

Longe estamos do náufrago na ilha deserta, embora o termo náufrago dê título ao romance de Bernhard, além de aparecer algumas vezes no texto, como ocorre no fragmento em epígrafe, no qual se destaca um elo sádico entre Glenn Gould e Wertheimer, trazido à baila pela focalização memorialista do narrador, o que culmina por envolver os três nessa modalidade de relação. A marca da corrosão integra também a curiosa amizade entre eles carcomida pela traça da inveja e do narcisismo, dentre outras forças destrutivas.

A modalidade dos afetos de origem sadomasoquista não está ausente do relacionamento que se estabelece entre Robinson e Sexta-Feira, no romance de Defoe (1719), do qual $O$ náufrago tanto se distancia. A dominação entre senhor e escravo permanece oculta para o leitor interessado no perfil arrojado e ativo do protagonista do Robinson Crusoe. 
No mundo colonizado pelos robinsonianos, o teor de submissão e vassalagem, de crueldade e sadismo recebe a bênção da ideologia do conquistador, que explora o gentio utilizando-se do álibi de um processo civilizatório que se apresenta como o melhor. No mundo do entre guerras do Império Austro-Húngaro e do pós-guerra e da Guerra Fria em que decorre o relacionamento dos três pianistas, a corrosão é princípio estruturador de uma narrativa em que o sadismo vem à tona, como força propulsora da força textual.

O texto de Bernhard também se entrecruza com outra tradição, a dos romances aos quais a crítica tem atribuído a ideia de formação, e na qual o sadomasoquismo é evocado, como no caso de The confusions of young Törless (2001), de Musil, citado explicitamente em suas páginas. Não que $O$ náufrago deva ser incluído na série de romances de formação, mas com sua referência ao livro de Musil, Bernhard retoma o sadismo que se estabelece entre os alunos da escola do Império Austro-Húngaro frequentada pelo jovem Törless.

O texto de Musil lembra, no caso da ficção brasileira, o clima do internato em que estuda Sérgio, personagem de O Ateneu (1888), de Raul Pompeia. Na literatura brasileira atual, Diário da queda (2011), de Michel Laub, trata, de forma renovadora, esse tema, articulando-o com o exílio 
e o transplante entre culturas. Em Laub, trata-se das marcas deixadas pelas formas de viver o judaísmo no mundo não judaico da sociedade brasileira gaúcha na fase da imigração causada pela II Guerra Mundial. O belo texto de Michel Laub fabrica uma trama sensível que agarra o leitor, manejando com a memória lembrada e a inventada, ao mesmo tempo, numa construção que toma a repetição (da memória do avô, por exemplo, no registro que deixa ao saber que tem o mal de Alzheimer) como chave magnífica de construção da narrativa. O texto recomeça várias vezes, com o personagem simulando voltar sempre ao diário do avô, construindo sua escrita sobre a escrita de outrem, isto é, a do neto, a partir da qual também se tem a imagem do pai.

Em Diário da queda, culpa e sadomasoquismo, solidão e rememoração, conjugam perspectivas e sentimentos que alimentam o jovem torturando pelo ato de remoer, afundando-se não só por essas memórias, mas também pelo mundo oceânico do alcoolismo em que se lança. Outra obra que retrabalha e questiona o veio das narrativas de formação, desconstruindo fórmulas passadas, a ser lembrada no campo da literatura brasileira é a intrigante Armadilha para Lamartine, de Carlos Süssekind (1976), no qual a escrita em palimpsesto, acrescida do tema da loucura, traça o percurso 
originalíssimo da formação do jovem, a partir da escrita do diário do pai, que o interna como louco, texto de que o filho se apossa, enquanto autor fictício.

Relendo-se $O$ náufrago de Bernhard, surge uma pergunta: o que nele foi feito do conquistador, à maneira do Robinson Crusoe, e do promeneur, com seu tanto de flânérie, de Rousseau? Numa primeira percepção, vê-se que o conceito de naufrágio sai da fatura da denotação e do eixo da utopia do self-made man, aquele que faz a si mesmo um cidadão pela iniciativa e trabalho, uma vez que a sociedade igualitária, com que sonhou a revolução francesa, não se constitui como tal.

Além disso, os alicerces do capitalismo, em seu desenvolvimento desde o século XVIII, não atendem à mitologia que a imagem do Robinson parecia propor, pois o que o homem social obtém não se apresenta mais como algo que se coaduna com a sua vontade: o ego volitivo que, segundo Hannah Arendt, tinha sido a criação da filosofia romântica, não determina a correspondência entre o que se deseja e o que de fato se obtém pelo trabalho.

Como propõe o historiador marxista Eric Hobsbawm (1986), o século $X X$, com suas duas grandes guerras e a destruição trazida, mostra que a capacidade desejante do sujeito não corresponde (nem nunca correspondeu, de fato) 
a seu empenho e trabalho, como parecia sugerir o lluminismo, que apresentava a racionalidade técnico-científica como capaz de domar até o destino inóspito, transformando a imagem do indivíduo num dínamo da produção ininterrupta de bens, sendo o homem visto como um ser competente para acumular os proveitos dessa transformação operosa.

Numa segunda observação, comparando-se o que ocorre neste romance de Bernhard, O náufrago, com o que ocorre na narrativa de Defoe (1719), Robinson Crusoe, percebe-se que a ambiência na qual vive a trinca de personagens, com sua caracterização e destino trágico, se distancia do ego volitivo de um Robinson cheio de operosidade, que vence o meio hostil (e, ao mesmo tempo, enriquece pelo trabalho escravo executado em sua propriedade de plantação de fumo em uma colônia europeia do hemisfério sul). A obra de Bernhard distingue-se também como repúdio do movimento de interiorização em busca do eu profundo que encontraria na natureza o seu outro, a espelhar-lhe a alma, o coração, o imaginário de incessante movimento e delírio, como propunha Rousseau e vieram a reafirmar, posteriormente, os primeiros românticos. Não há inocência, nem inocentes em $O$ náufrago.

Sua narrativa faz esboroar o mito do progresso pelo trabalho que, segundo Zygmunt Bauman (2001), deu origem 
à fase do capitalismo sólido, que terminaria com o fordismo, por volta dos anos 1960 e fundou boa parte da euforia da modernidade. As considerações em discurso indireto livre, feitas pela dona da pousada, demonstram o ressentimento com que ela observa seus clientes e, ao mesmo tempo, discutem o clima de separação e isolamento não só entre as classes, mas a dificuldade de acesso às emoções e a compreensão, com fraternidade, dos interesses distintos de cada um e de cada grupo, fragmentados, sem solidariedade possível:

Mas esses senhores refinados não faziam ideia do que era viver como ela vivia, administrar uma pousada como o Moinho de Dichtel. Eles (os senhores refinados!) só ficavam falando de seus assuntos incompreensíveis, não tinham que se preocupar com nada e passavam o tempo todo refletindo sobre o que fazer com seu dinheiro e com seu tempo. Ela própria nunca tivera dinheiro e tempo suficientes, nem sequer fora única e exclusivamente infeliz, ao contrário daqueles a quem tinha chamado senhores refinados, os quais sempre tinham tido tempo e dinheiro suficientes e ficavam falando a toda hora de sua própria infelicidade. Ela não conseguia entender que Wertheimer sempre lhe disse ser uma pessoa infeliz. (BERNHARD, 2006, p.117-118)

A forma estilística escolhida pela tradução faz acentuar, pela repetição de palavras e construções frasais e mesmo de ideias repisadas, o mundo de confinamento de cada um 
deles, presos, inclusive ela, em seus casulos de reclamações, solidão, ressentimento e mágoa, no qual fica evidenciada a ausência de alteridade. $E$, à maneira de um estilhaço que se deslocasse, uma velha conhecida se reapresentou: a metáfora do naufrágio, agora modulada na chave não mais da salvação de um homem vigoroso e cheio de coragem, como Crusoé, mas à conexão entre a questão da solidão e do naufrágio visto como mutilação, infelicidade (sem causa, para a estalajadeira).

Em A solidão tropical, ao tratarmos da construção da modernidade na Europa e no Brasil, postulamos que a metáfora do naufrágio, utilizada por Defoe no século XVIII, inaugurava um novo sentido, distinto do que com ela ocorria na Antiguidade e até no lluminismo: o naufrágio de Robinson na ilha deserta traz para esse náufrago a simbologia não mais do azar, mas a da criação de um novo gestor da aventura, de alguém capaz de inventar mundo novo a partir dos restos do mundo anterior, gerando, assim, uma forma de interpretação da cultura na modernidade e o exame da subjetividade dessa cultura e do personagem "fundador". Em O náufrago, a metáfora náutica abre outra rede de metamorfose e dispersão para veicular as questões da sensibilidade, da economia psíquica de cada um e do grupo 
e da exclusão humana que fica patente entre as classes. O livro torna-se ainda mais interessante ao mostrar, sem qualquer tom de panfleto social, o que o empobreceria, que a mesma dificuldade encontrada pela administradora do Moinho Dichtel de compreender Wertheimer e o mundo das pessoas refinadas é vista por outro ângulo, o de Wertheimer e o do narrador:

Em vez de ir agora a Traich, eu, no fundo, teria preferido ficar sentado no salão, ouvindo a conversa dos entregadores de cerveja com a dona da pousada, pensei ao sair; teria preferido sentar-me à mesa dos entregadores de cerveja e beber com eles um copo de cerveja. Volta e meia nós nos imaginamos sentados na companhia daqueles por quem a vida toda nos sentimos atraídos, justo dessas pessoas simples, que naturalmente imaginamos bem diferentes do que são na verdade, pois se nos sentamos de fato em sua companhia, veremos que elas não são como pensávamos, e que ao contrário do que incutimos em nossa cabeça, não pertencemos em absoluto ao seu meio; [...]. A vida toda ansiamos por essas pessoas, queremos ir até elas, e quando demonstramos o que sentimos por elas somos repelidos, e com a maior desconsideração aliás. Wertheimer sempre contava que fracassou nessa sua ânsia de estar com as chamadas pessoas simples e, portanto, com o chamado povo, nessa ânsia de pertencer a seu meio [...]. (BERNHARD, 2006, p.119-120) 
Em $O$ náufrago e em outros romances que comentamos, mesmo aqueles em que a metáfora do naufrágio não se apresenta claramente, ocorre uma alteração de rumos da linguagem. A linguagem não descreve, não conta como é a paisagem. A paisagem, ainda que por vezes descrita, é coisa da escrita. Cena mental que toca o limite da linguagem. A questão da subjetividade e a da sensibilidade também encontra novas formas de encaminhamento: uma rede de repetições constrói um cavalgamento de uma sensação na outra, que a repete e diferencia, com sutilezas de mudança de ângulo, colocando em metamorfose a verdade e o sentimento ao mudar de ponto de vista. Isso vai acumulando de sombras a comunicação interpessoal e refutando a compreensão da linguagem como comunicação e transparência. Como para os tragediógrafos gregos, essa ficção do naufrágio da existência opera com a tensão entre a verdade e o engano, trabalhando a linguagem como revelação e encobrimento.

A própria metáfora do naufrágio, em sua força, ao mesmo tempo, de construção e de interpretação cultural, ganha labilidade, mostrando que o paradigma ficcional - a série romanesca de que se está tratando - tem afinidades com a acurada leitura de Bauman, de que se vive hoje outra fase do capitalismo, líquida, com as características que ele atribui ao termo, que examinei em livro anterior (HELENA, 2010). 
A própria metáfora do naufrágio, na série romanesca de que estamos tratando, e, neste momento, em especial em $O$ náufrago, revela o espessamento da linguagem que se torna pantanosa, algo infiel ao narrador e ao leitor, carentes dos limites do significado e expostos à forma rizomática do processamento mais rico e mais denso da significação que se espraia sem teleologia ou finalidade de apontar o fechamento do sentido.

A técnica de repetição forma um eco deformado, uma distorção que impede resposta clara às demandas do existir. Entre a memória e a invenção da matéria de que se vale o narrador para contar o seu relato, após a morte de Wertheimer e também de Glenn Gould, o discurso narrativo funciona como um sobrevivente e o ato da escrita é a forma de grafar um navegar pela vida, um "navegar é preciso viver" que, se não redime, nem leva à compreensão dos motivos pelos quais todos eles, inclusive aquele que escreve o relato, sucumbem à infelicidade, pelo menos funciona como uma forma de renascimento, pelo texto, de não se ficar alheio à palavra nem à literatura.

No entanto, essa é uma literatura que não acredita mais em si mesma como representação de um mundo verossímil ou de uma verdade a ser formulada pela narração. 
Essa é uma literatura que discute a fatura da linguagem, a fatura do virtuose da linguagem que, trabalhando com o termo náufrago, faz com que o leitor medite acerca da forma como é escrita a narrativa; perceba que é preciso continuar a questionar, a processar o sentido para além do conteúdo último e do significado único. Na busca de abandonar o horizonte da palavra que se plenifica, o narrador de $O$ náufrago escreve o que chama "essas absurdidades", "essas manifestações ensaísticas" (BERNHARD, 2006, p.92).

Se anteciparmos um breve comentário sobre o trabalho de linguagem realizado por Coetzee (1987) em Foe, que analisaremos no capítulo seguinte, e o compararmos ao que empreende Thomas Bernhard, perceberemos que ambos discutem, ainda que por diferentes estratégias, a metamorfose e crítica não só da mitologia fundadora do capitalismo e da construção do sujeito burguês, mas também e refinadamente, a trajetória da representação pela literatura e a insuficiência da compreensão da literatura como mera representação.

O romance de Thomas Bernhard examina, a partir do drama vivido por três personagens em face de sua vocação para a arte do piano, as paixões mortais que habitam o homem, como o narcisismo, a inveja, a incapacidade 
de aceitar limitações e de estabelecer a amizade e fraternidade como um valor. Em dado momento, o narrador explica o título do livro:

Glenn tinha o maior apreço pela palavra náufrago e por seu significado; lembrome bem; foi na Sigmund-Haffner-Gasse que o náufrago the veio à mente. Quando observamos as pessoas, só vemos mutilados, Glenn nos disse certa vez; mutilados interiormente, exteriormente ou ambas as coisas, e é só o que se vê, pensei. [...] O mundo está cheio de mutilados. (BERNHARD, 2006, p.31)

É acerca desse mundo de personagens mutilados, náufragos da esperança, que se vai desenrolar a narrativa. Mas não só: é também acerca da mutilação da linguagem, da carência da linguagem, da carência do virtuose em executar sua grande arte. Se os três jovens e talentosos músicos podem ser considerados todos os três capazes de serem virtuoses no desempenho profissional, apenas um deles, Glenn Gould, é considerado um gênio. O livro também discute, nesse sentido, a concepção do escritor, do artista, como gênio, e a reencaminha noutra direção. Glenn carrega o conceito de gênio, que esteve a serviço da estética burguesa. Ele é um personagem híbrido não só porque pertence tanto ao universo ficcional da obra, quanto ao mundo "real" da música, como figura histórica de reconhecimento internacional, 
por ser considerado o mais importante executor das Variações Goldberg, de Bach. Sobre ele, diz a narrativa que "[o] fato é que quando veio para a Europa fazer o curso de Horowitz, Glenn já era um gênio, enquanto nós, na mesma época, já éramos os fracassados, pensei. No fundo eu não queria ser um virtuose do piano" (BERNHARD, 2006, p.50 grifo nosso).

A categoria do gênio, qualidade ambicionada por Wertheimer, Glenn e pelo próprio narrador, é o que ajuda a exterminar o pouco de equilíbrio que mantinha Wertheimer vivo. Ser um gênio era um valor tão ambicionado por ele que, para consegui-lo, poderia matar e morrer, a ponto de suicidarse. As categorias do gênio e a da literatura de formação, bem como a concepção da literatura como representação sofrem, na narrativa de Bernhard, um processo de desconstrução que as dessacraliza, num torvelinho de repetições e versões e na composição prismática de pontos de vista, à maneira de uma composição cubista.

A narrativa em torvelinho não obedece mais ao traço realista de sequência causal, mas a um fluxo descontínuo comum aos modernistas de inícios do século $X X$, retomados aqui com um traço de articulação existencialista e da estética do absurdo. Mas, diferentemente dos modernistas, o texto não se torna hermético. 
O livro tem apoio na estratégia da repetição e, evidentemente, na reiteração (em metamorfose) do tema do náufrago, em relevo desde seu título. Mas, ainda que derrotado e suicida, o náufrago é apresentado como um personagem potencialmente contagioso, como no fragmento a seguir:

Nós nos deparamos continuamente com esses náufragos e homens sem saída [...]. Temos o maior trabalho para nos salvar desses náufragos e homens sem saída, pois tanto os náufragos quanto os homens sem saída fazem de tudo para tiranizar o mundo a seu redor, para acabar com seus semelhantes. (BERNHARD, 2006, p.70)

A narrativa trabalha obsessivamente a relação dos três amigos. Como em um processo de neurose, a estrutura da repetição se faz presente no estilo. Em dois momentos culminantes, sua convivência é focalizada: inicialmente em 1953, quando o narrador e Wertheimer escutam pela primeira vez a execução de Glenn Gould das Variações Goldberg, de Bach. O segundo momento ocorrerá 28 anos depois, quando o personagem narrador visita a casa de campo de Wertheimer em Traich, após o suicídio desse amigo. Como se sabe, os três haviam se conhecido no Mozarteum, quando estudaram piano com Horowitz e, segundo o narrador e Wertheimer, Glenn, o americano-canadense, se destacou como melhor 
do que o próprio professor, tido então, pelos dois europeus, como o melhor executor daquela peça: "Terminado o curso, ficou claro que Glenn era já melhor pianista do que o próprio Horowitz, e, daquele momento em diante, Glenn passou a ser para mim o virtuose de piano mais importante de todo o mundo" (BERNHARD, 2006, p.8).

O náufrago examina, pois, a dissolução da subjetividade, concentrando-a, estrategicamente, na extrema dificuldade que os três pianistas demonstram de conseguir estabelecer sua relação no eixo da admiração, que é trocado, ao longo da convivência, pelo insuportável narcisismo que os impede de cultivar, na amizade, a diferença. Inicialmente, eles parecem não se dar conta do que ocorre, mas tanto a crueza da crítica de Glenn contra Wertheimer, que ele toma como um perdedor, quanto o prazer lascivo de narrar a desgraça daquela amizade, como ocorre no discurso do narrador, aportam um nível de consciência e de sádico prazer, que aflora para o leitor mais atento. Não deixando de lado o fato de que Wertheimer tem, dentre as motivações para o suicídio, a extrema competição (e a invejosa admiração) com o virtuosismo de Glenn Gould, a relação dos três entre si acaba por adotar o mesmo tipo de veneno. Retroalimentando-se, o sadismo assume forma mortal, condenando-os à morte 
e ao silêncio, também reservando ao trato das identidades, nessa narrativa, um sempre patinar no limbo do abjeto e da rejeição.

Técnica virtuosa, fama, treinamento extenuante, dedicação obsessiva à carreira e competição pela excelência levam os três personagens a peregrinarem seus eus fragmentados, perfazendo uma errância em que a morte dinamita as possibilidades de expressar, para si mesmos e uns para os outros, a afetividade que, por outro lado, também os reúne em uma tortuosa amizade que se extingue nas mortes de Wertheimer e Glenn Gould, encenadas e reencenadas pelo texto do único sobrevivente, que ocupa a posição de narrador do romance. Diante da dor dos homens, a literatura de Bernhard, entre o silêncio e o dizer, não se cala.

\section{REFERÊNCIAS}

AGAMBEN, Giorgio (2002). Idea della prosa. Macerata, Itália: Quodlibet. BAUMAN, Zygmunt (2001). Modernidade líquida. Plínio Dentzien (Trad.). Rio de Janeiro: Zahar.

BAZZANA, Kevin (2011). The loser reviewed. In http://www. collectionscanada.gc.ca/ glenngould/028010-40.05.07-e.html Acesso em 07.Dez.2011.

BERNHARD, Thomas (2006). O náufrago. 2.ed. Sergio Tellaroli (Trad.). São Paulo: Companhia das Letras.

BLUMEMBERG, Hans (1997). Shipwreck with spectator. Paradigm of a metaphor for existence. Steven Rendall (Trad.). Cambridge, Massachusetts: The MIT Press. 
COETZEE, John Maxwell (2001). Stranger shores: literary essays. 19861999. London: Penguin Books.

(1987). Foe. A novel. New York: Penguin Books.

(2001). Introduction. In MUSIL, Robert. The confusions of Young

Törless. New York: Penguin Books, p.v-xiii.

DEFOE, Daniel (1719). Robinson Crusoe. John Richetti (Intr. and notes). London: Penguin Books.

HELENA, Lucia (2006). A solidão tropical. A modernidade do Brasil e de Alencar. Porto Alegre: Editora PUC-RS.

(2010). Fiç̧̃es do desassossego. Fragmentos da solidão contemporânea. Rio de Janeiro: Contra Capa.

(2016). Náufragos da esperança. A literatura na era da incerteza. 1.ed. ampliada. Rio de Janeiro: Oficina Raquel.

HOBSBAWM, Eric (1986). A era das revoluções: 1789-1848. Maria Tereza Lopes Teixeira e Marcos Penchel (Trad.). 5.ed. Rio de Janeiro: Paz e Terra. LAUB, Michel (2011). Diário da queda. São Paulo: Companhia das Letras. MUSIL, Robert (2001). The confusions of Young Törless. Transl. from German by Shaun Whiteside with an intr. by J. M. Coetzee. New York: Penguin Books.

NUNES, Bendito (1989). "Clarice Lispector ou o naufrágio da introspecção". In Remate de Males, 9, 63-70.

ROUSSEAU, Jean-Jacques [s.d.]. As confissões. Wilson Lousada (Trad.). Rio de Janeiro: Ediouro.

SUSSEKIND, Carlos (1976). Armadilha para Lamartine. São Paulo: Cia das Letras.

Lucia Helena é Professora Titular da UFF (Aposentada), Professora Adjunta da UFRJ (Aposentada), Pesquisadora de Produtividade Nível 1-A do CNPq. Doutora em Teoria da Literatura pela UFRJ (1983); PósDoutora em Literatura Comparada pela Brown University, 1989); Além de ter publicado inúmeros artigos em revistas nacionais e internacionais (Portugal, Estados Unidos, Hungria) e inúmeros capítulos de livros no 
Brasil e no Exterior (Europa, Estados Unidos). É autora, dentre outros, dos livros: Uma literatura antropofágica, Totens e tabus da modernidade brasileira (Prêmio Sociedade Paulista de Criticos de Arte de ensaio), Nem musa, nem medusa, A solidão tropical, Ficções do Desassossego, Náufragos da Esperança, e Uma Literatura Inquieta, este de parceria com Paulo César de Oliveira. 